\title{
Effect of mixed silanes on the hydrolytic stability of composites
}

\author{
R.G. CRAIG \& E.R. DOOTZ School of Dentistry, The University of Michigan, Ann Arbor, MI, U.S.A.
}

SUMMARY A filler for a urethanedimethacrylate composite was silanated with mixtures of fluoroalkyl-, aminoalkyl-, phenyl-, vinyl-, bis silyl ethane- and 3methacryloxypropyltrimethoxysilane (MAOP) in an attempt to increase the hydrophobicity of the coupling agent layer. Diametral tensile strength was used to evaluate compositesstored for (1) $24 \mathrm{~h}$ in $23^{\circ} \mathrm{C}$ (RT) air; (2) $24 \mathrm{~h}$ in RT air plus $24 \mathrm{~h}$ in $100^{\circ} \mathrm{C}$ air; (3) $24 \mathrm{~h}$ in RT air plus $24 \mathrm{~h}$ in $100^{\circ} \mathrm{C}$ water; and (4) $24 \mathrm{~h}$ in $R T$ air plus $24 \mathrm{~h}$ in $100^{\circ} \mathrm{C}$ air plus $24 \mathrm{~h}$ in $100^{\circ} \mathrm{C}$ water. Water sorption and solubility of composites was also determined on samples stored for $24 \mathrm{~h}$ in RT air. Heating composites for $24 \mathrm{~h}$ in $100^{\circ} \mathrm{C}$ air increased the tensilestrength in eight of 13 silanetreatments, while heating in $100^{\circ} \mathrm{C}$ water for $24 \mathrm{~h}$ caused decreases for five silane treatments, no change for six and increases in tensile strength for two silane treatments. When composites that had been stored for $24 \mathrm{~h}$ at RT plus heated for $24 \mathrm{~h}$ in $100^{\circ} \mathrm{C}$ air were then heated for $24 \mathrm{~h}$ in $100^{\circ} \mathrm{C}$ water, only one silane treatment, the vinyltriethoxysilane at $25 \%(25 \% \mathrm{~V})$, showed no significant decrease in tensile strength. Also, the compositesilanated with $25 \% \mathrm{~V}$ had the highest value for tensile strength after storing for $24 \mathrm{~h}$ at $\mathrm{RT}$ air plus $24 \mathrm{~h}$ in $100^{\circ} \mathrm{C}$ air plus $24 \mathrm{~h}$ in $100^{\circ} \mathrm{C}$ water. These data indicatethat the use of vinyltriethoxysilane increases the hydrolytic stability of the composite. Water sorption and solubility of the silanated composites were not satisfactory tests for evaluating hydrolytic stability of composites.

\section{Introduction}

The hydrolytic stability of composites has been shown by Söderholm et al. (1984) to be an important factor in their service life. Earlier, Schrader, Lerner \& D'Oria (1967) had used radiotagged silanes to demonstrate that coupling agents in reinforced plastics formed covalent bonds to silica, a hydrogen bonded layer, and the molecules were condensed by cohesive forces. Later, Nishiyama, Katsuki \& Horie (1987) measured the adsorption of 3-methacryloxypropyltrimethoxysilane (MAOP), on colloidal silica, and demonstrated that both monolayer and multilayer adsorption occurred. Söderholm \& Shang (1993) studied the molecular orientation of MAOP on colloidal silica and proposed that the amount of silane needed for surface treatment depended on the number of isolated hydroxy groups available on the surface of the filler. Chen $\&$ Brauer (1982) found that the presence of $2 \% \mathrm{n}$-propylamine with MAOP increased the silanization on silica and yielded a more stable silane bond as shown by increases in tensile strength and water resistance of composites containing these treated fillers. Nishiyama et al. (1986) studied the effect of functional groups of silanes on the adhesion of composite to silanated glass. Of those silanes which gave reasonable tensile adhesion the methacryoxypropyl group gave the highest value followed by vinyl- and mercaptopropyl-. They also measured contact angles of Bis-GMA on silanated glass and found the highest contact angle of $42^{\circ}$ for glass treated with vinyltriethoxysilane. Kurata \& Yamazaki (1988) used 3-methacryloxypropyltriisocyanatosilane to treat silica surfaces and found higher adhesive strength of poly(methyl methacrylate) to the treated glass than 
when treated by MAOP; this result was explained by the higher reactivity of the isocyanato group compared to the ethoxy group. The authors claimed better water resistance resulted because of this reactivity and a higher crosslinking in the siloxane phase. Umemoto et al. (1990) mixed 3-mercaptopropyltrimethoxysilane with MAOP and used the mixture as a primer for adhesion of poly (methyl methacrylate) to stainless steel and glass and found the mixed silanes were highly adhesive with tensile values after 3 days in $37^{\circ} \mathrm{C}$ water of 23 and 17 $\mathrm{MPa}$, respectively. Rosenstiel et al. (1993) studied the use of fluoroalkylethylsilane as a coating for a moisture barrier for dental ceramics and found it reduced the stress corrosion in glass and feldspathic porcelain.

Thus, it appears that increasing the hydrophobicity of the silane should increase the hydrolytic stability of the coupling layer and the service life of a composite. Fluorinated silanes would seem to be a logical choice, but unfortunately they are not available with reactive double bonds to react with the monomers and oligomers of the composite during setting. An al ternative approach would be to use mixtures of saturated fluoroalkyltrialkoxysilanes and MAOP. Mixtures of other silanes having hydrophobic groups such as phenyl- or vinylcould improve the hydrolytic stability of composites. Since $\mathrm{n}$-propylamine has been shown to improve silanization of MAOP, addition of aminopropyltrimethoxysilane might be useful. Finally, the addition of bisfunctional silanes such as 1,2-bis(trimethoxysilyl)ethane might improve the stability of the coupling agent layer by improving the crosslinking of the silane. It was the purpose of this study to evaluate the above types of mixtures of silanes on the hydrolytic stability of composites by determining their diametral tensile strength after accelerated ageing in water and by measuring the water sorption and solubility of the composites.

\section{Materials and methods}

Silanes used plus their codes are listed in Table 1. The silanes were obtained from Hüls America, Inc., Piscataway, NJ, U.S.A. Zrrconia-silica, having an average particle diameter of $1.6 \mu \mathrm{m}$, was silanated at three times the amount needed to obtain a minimum uniform surface coverage. This amount of silane was calculated according to the formula described by Mohsen \& Craig (1995). Silanation, except when using BTMSE or BTCSE, was undertaken using $25 \%$ or $50 \%$ TDF, TFP, AP, $\mathrm{P}$ and $\mathrm{V}$ with the balance being MAOP. The bis-ethanes were used at $10 \%$ with the bal ance being 25\% TFP and 65\% MAOP. Silanation was done from ethanol solutions of the silanes as described by Mohsen $\&$ Craig (1995) using a tumbling time of $90 \mathrm{~min}$ in a sealed polyethylene round bottle.

The polymer was a urethanedimethylacrylate containing $\quad 10 \% \quad$ 1,6-hexanedioldimethacrylate*. Composite pastes were formulated by hand with 19.75 wt. $\%$ of the above with 80 wt. $\%$ of the silanated filler, 0.152 wt.\% dl-camphoroquinone, and 0.9 wt.\% of $\mathrm{N}, \mathrm{N}$-dimethylaminoethylmethacrylate.

The pastes were placed in stainless steel moulds $6 \mathrm{~mm}$ in diameter and $3 \mathrm{~mm}$ high for diametral tensile strength specimens and $50 \mathrm{~mm}$ diameter and $1 \mathrm{~mm}$ high for water sorption and solubility specimens. The top of the moulds were covered with a glass slide and initial polymerization was accomplished with blue light ${ }^{\dagger}$. The end of the light wand completely covered the end of the diametral tensile specimen and a $90 \mathrm{~s}$ exposure was used; the specimen was unmoulded and was cured for an additional hour in an Astron XL light unit ${ }^{\ddagger}$. Initial curing of the water sorption and solubility specimens was carried out for 4 min with the light wand scanned over the wide surface; the specimens were unmoulded and further cured for $1 \mathrm{~h}$ in the Astron XL light unit.

The diametral tensile strength (DTS) of the specimens was determined after four storage conditions: (1) after $24 \mathrm{~h}$ storage in air at $23^{\circ} \mathrm{C}$ (RT); (2) after $24 \mathrm{~h}$ in RT air followed by $24 \mathrm{~h}$ in air at $100^{\circ} \mathrm{C}$; (3) after $24 \mathrm{~h}$ in RT air followed by $24 \mathrm{~h}$ in distilled water at $100^{\circ} \mathrm{C}$; and (4) after $24 \mathrm{~h}$ in RT air followed by $24 \mathrm{~h}$ in air at $100^{\circ} \mathrm{C}$ and then $24 \mathrm{~h}$ in distilled water at $100^{\circ} \mathrm{C}$. Diametral tensile strengths were determined at RT in an Instron ${ }^{\S}$ at a crosshead speed of $0.5 \mathrm{~mm} / \mathrm{min}$. The ends of the specimens were cushioned by a piece of file cardboard $0.3 \mathrm{~mm}$ thick. Five specimens were tested for each silane and each storage condition.

Water sorption and solubility tests were conducted according to A.D.A. specification no. 12 for denture base polymers (1975). Three specimens were tested for each silane treatment.

\footnotetext{
*Esschem Co., Essington, PA, U.S.A.

${ }^{\dagger}$ Marathon unit by Den Mat Corporation, Santa Maria, CA, U.S.A.

${ }^{\ddagger}$ Astron Dental Corporation, Wheeling, IL, U.S.A.

${ }^{\S}$ Canton, MA, U.S.A.
} 


\begin{tabular}{|c|c|}
\hline Silane & Code \\
\hline $\mathrm{CH}_{2}=\stackrel{\mathrm{C}}{\mathrm{C}}-\mathrm{C}-\mathrm{OCH}_{2} \mathrm{CH}_{2} \mathrm{CH}_{2}-\mathrm{Si}\left(\mathrm{OCH}_{3}\right)_{3}$ & \\
\hline $\begin{array}{l}\text { O } \\
\text { 3-methacryloxypropyltrimethoxysilane }\end{array}$ & MAOP \\
\hline $\begin{array}{l}\mathrm{CF}_{3}\left(\mathrm{CF}_{2}\right)_{5} \mathrm{CH}_{2} \mathrm{CH}_{2}-\mathrm{Si}\left(\mathrm{OCH}_{2} \mathrm{CH}_{3}\right)_{3} \\
\quad \text { tridecafluoro-1,1,2,2-tetrahydroocytl-1-triethoxysilane }\end{array}$ & TDF \\
\hline $\begin{array}{l}\mathrm{CF}_{3} \mathrm{CH}_{2} \mathrm{CH}_{2}-\mathrm{Si}\left(\mathrm{OCH}_{3}\right)_{3} \\
\quad \text { (3,3,3-trifluoropropyl)trimethoxysilane }\end{array}$ & TFP \\
\hline $\begin{array}{l}\mathrm{NH}_{2} \mathrm{CH}_{2} \mathrm{CH}_{2} \mathrm{CH}_{2}-\mathrm{Si}\left(\mathrm{OCH}_{3}\right)_{3} \\
\text { 3-aminopropyltrimethoxysilane }\end{array}$ & AP \\
\hline $\begin{array}{l}\langle\underline{\mathrm{O}}\rangle-\mathrm{Si}\left(\mathrm{OCH}_{2} \mathrm{CH}_{3}\right)_{3} \\
\text { phenyltriethoxysilane }\end{array}$ & $P$ \\
\hline $\begin{array}{l}\mathrm{CH}_{2}=\mathrm{CHSi}\left(\mathrm{OCH}_{2} \mathrm{CH}_{3}\right)_{3} \\
\text { vinyltriethoxysilane }\end{array}$ & V \\
\hline $\begin{array}{l}\left(\mathrm{CH}_{3} \mathrm{O}\right)_{3} \mathrm{SiCH}_{2} \mathrm{CH}_{2} \mathrm{Si}\left(\mathrm{OCH}_{3}\right)_{3} \\
\text { 1,2-bis(trimethoxysilyl)ethane }\end{array}$ & BTMSE \\
\hline $\begin{array}{l}\mathrm{Cl}_{3} \mathrm{SiCH}_{2} \mathrm{CH}_{2} \mathrm{SiCl}_{3} \\
\text { 1,2-bis(trichlorosilyl)ethane }\end{array}$ & BTCSE \\
\hline
\end{tabular}

Table 1. Silanes used for silanation and their codes

\section{Results}

The diametral tensile strengths of the composites with various silanated fillers are reported in Table 2 along with their standard deviations in parentheses. Table 3 indicates whether there was a statistical difference at the $95 \%$ confidence level between the value for the $24 \mathrm{~h}$ in RT air specimen (control) and the values for the other three conditions. A statistical comparison was also made between samples stored for $24 \mathrm{~h}$ at RT followed by $24 \mathrm{~h}$ at $100^{\circ} \mathrm{C}$ in air and samples stored for $24 \mathrm{~h}$ at RT followed by $24 \mathrm{~h}$ in $100^{\circ} \mathrm{C}$ air and then $24 \mathrm{~h}$ in $100^{\circ} \mathrm{C} \mathrm{H}_{2} \mathrm{O}$. The results show that heating in air for $24 \mathrm{~h}$ at $100^{\circ} \mathrm{C}$ increased the tensile strength in eight of the silane treatments; caused no significant change in four of the treatments; and resulted in a significant decrease with only one silane treatment $(50 \% \mathrm{P})$. However, heating in water for $24 \mathrm{~h}$ at $100^{\circ} \mathrm{C}$ resulted in five significant decreases; six no significant changes; and two significant increases in tensile strength compared to the $24 \mathrm{~h}$ in RT air control. When specimens were heated in air at $100^{\circ} \mathrm{C}$ for $24 \mathrm{~h}$ followed by heating in water at $100^{\circ} \mathrm{C}$ for $24 \mathrm{~h}$, only two silane treatments resulted in no significant change in tensile strength and only one treatment ( $25 \% \mathrm{~V}$ ) having a significant increase compared to the control. When specimens that had been stored in RT air for $24 \mathrm{~h}$ followed by storage in $100^{\circ} \mathrm{C}$ air for $24 \mathrm{~h}$, were then stored in $\mathrm{H}_{2} \mathrm{O}$ for $24 \mathrm{~h}$ all but those silanated with $25 \% \mathrm{~V}$ showed a statistically significant decrease in tensile strength.

A statistical comparison of the magnitudes of the diametral tensile strengths of the various composites first heated in air at $100^{\circ} \mathrm{C}$ followed by heating in water at $100^{\circ} \mathrm{C}$ for $24 \mathrm{~h}$ each showed that silanation with $25 \% \mathrm{~V}$ resulted in significantly higher tensile strength values than any other treatment and there was considerable overlap in the ranking of the other treatments. Composites with fillers silanated with $25 \%$ TDF $+10 \%$ BTMSE, 25\% AP, 100\% MAOP, 25\% TDF, and $25 \%$ TPF had tensile strengths that were not statistically different at the $95 \%$ confidence level. Also, $25 \%$ AP, 100\% MAOP, 25\% TDF, 25\% TFP and 25\% P had tensile strengths that were not statistically different.

Water sorption and solubility values are listed in Table 4. The water sorption of composites with fillers 
Table 2. Diametral tensile strengths of composites with various silanated fillers, $\mathrm{kg} / \mathrm{cm}^{2}$

\begin{tabular}{|c|c|c|c|c|}
\hline Silane treatment* & After $24 \mathrm{~h}$ & $\begin{array}{l}\text { After } 24 \mathrm{~h}+ \\
24 \mathrm{~h} \text { in } 100^{\circ} \mathrm{C} \text { air }\end{array}$ & $\begin{array}{l}\text { After } 24 \mathrm{~h}+ \\
24 \mathrm{~h} \text { in } 100^{\circ} \mathrm{C} \mathrm{H}_{2} \mathrm{O}\end{array}$ & $\begin{array}{l}\text { After } 24 \mathrm{~h}+24 \mathrm{~h} \text { in } 100^{\circ} \mathrm{C} \text { air }+ \\
24 \mathrm{~h} \text { in } 100^{\circ} \mathrm{CH}_{2} \mathrm{O}\end{array}$ \\
\hline $100 \%$ MAOP & $501(34)$ & $554(91)$ & $379(45)$ & $319(35)^{\#}$ \\
\hline $25 \%$ TDF & $336(25)$ & $428(43)$ & $433(29)$ & $315(19)^{\#}$ \\
\hline $50 \%$ TDF & $285(36)$ & $372(25)$ & $321(71)$ & - \\
\hline $25 \%$ TFP & $435(31)$ & $596(82)$ & $501(66)$ & $298(27)^{\#}$ \\
\hline $50 \%$ TFP & $397(71)$ & 433(32) & $489(41)$ & - \\
\hline $25 \% \mathrm{AP}$ & $459(39)$ & $545(56)$ & $459(41)$ & $342(48)^{\#+}$ \\
\hline $50 \%$ AP & $459(40)$ & $560(66)$ & $357(48)$ & - \\
\hline $25 \% \mathrm{P}$ & $435(40)$ & $472(93)$ & $444(41)$ & $311(46)^{\dagger}$ \\
\hline $50 \% P$ & $449(40)$ & $308(17)$ & $312(47)$ & - \\
\hline $25 \% \mathrm{~V}$ & $389(47)$ & $545(88)$ & $348(41)$ & $508(26)$ \\
\hline $50 \% \mathrm{~V}$ & $440(44)$ & $524(36)$ & $309(47)$ & - \\
\hline $25 \%$ TDF $+10 \%$ BTMSE & $402(70)$ & $551(68)$ & $382(38)$ & $390(63)^{\#}$ \\
\hline $25 \%$ TDF $+10 \%$ BTCSE & $347(31)$ & $381(41)$ & $159(25)$ & - \\
\hline
\end{tabular}

*Balance of silane used in treatment was MAOP; ${ }^{*}$ values not statistically different at $95 \% ;{ }^{\dagger}$ values not statistically different at $95 \%$.

Table 3. Comparison of storage in air and/or water at $100^{\circ} \mathrm{C}$ with storage for $24 \mathrm{~h}$ at RT (control), or with storage in RT air plus $100^{\circ} \mathrm{C}$ in air versus $24 \mathrm{~h}$ at $\mathrm{RT}$ followed by $100^{\circ} \mathrm{C}$ air and $100^{\circ} \mathrm{C}$ water*

\begin{tabular}{lllll}
\hline Silane treatment & $\begin{array}{l}24 \mathrm{~h} \text { in } 100^{\circ} \mathrm{C} \\
\text { air vs. control }\end{array}$ & $\begin{array}{l}24 \mathrm{~h} \text { in } 100^{\circ} \mathrm{C} \\
\mathrm{H}_{2} \mathrm{O} \text { vs. control }\end{array}$ & $\begin{array}{l}24 \mathrm{~h} \text { in } 100^{\circ} \mathrm{C} \text { air }+ \\
24 \mathrm{~h} \text { in } 100^{\circ} \mathrm{C}\end{array}$ & $\begin{array}{l}24 \mathrm{~h} \text { in RT air }+24 \mathrm{~h} \text { in } 100^{\circ} \mathrm{C} \text { air } \\
\text { vs. } 24 \mathrm{~h} \text { in } \mathrm{RT} \text { air }+24 \mathrm{~h} \text { in } 100^{\circ} \mathrm{C}\end{array}$ \\
\hline air $+24 \mathrm{~h}$ in $100^{\circ} \mathrm{C} \mathrm{H}_{2} \mathrm{O}$
\end{tabular}

$* \uparrow=$ condition was significantly higher than control; $\downarrow=$ condition was significantly lower than control; N.S. $=$ no significant difference between condition and control.

silanated with $50 \%$ AP and $50 \%$ V were the only ones statistically different at the $95 \%$ confidence level from $100 \%$ MAOP. Although the means of the water solubility for composites silanated with $\mathrm{V}$ were less than for the standard MAOP, statistical analysis indicated they were not different at the $95 \%$ level of confidence, based on a sample size of three and their standard deviations.

\section{Discussion}

Since the hydrolytic resistance of composites has been shown to be important in their service life (Söderholm et al., 1984), increasing the stability of the silanated interfacial layer between the organic matrix and the filler should improve the clinical quality of composites. Therefore, increasing the hydrophobicity of this interfacial layer would be a reasonable approach. The 
Table 4. Water sorption and solubility of composites with various silanated filters (\%)

\begin{tabular}{lll}
\hline Silane treatment* & Sorption & Solubility \\
\hline $100 \%$ MAOP & $1.58(0.39)$ & $0.33(0.17)^{\#}$ \\
$25 \%$ TDF & $1.44(0.13)$ & $0.32(0.04)^{\#}$ \\
$50 \%$ TDF & $1.39(0.08)$ & $1.12(0.01)^{\#}$ \\
$25 \%$ TFP & $1.39(0.06)$ & $0.43(0.04)^{\#}$ \\
$50 \%$ TFP & $1.29(0.07)$ & $0.36(0.02)^{\#}$ \\
$25 \%$ AP & $1.36(0.21)$ & $0.60(0.14)^{\#}$ \\
$50 \%$ AP & $0.73(0.06)$ & $0.13(0.07)^{\#}$ \\
$25 \%$ P & $1.27(0.03)$ & $0.61(0.06)^{\#}$ \\
$50 \%$ P & $1.25(0.17)$ & $0.66(0.11)^{\#}$ \\
$25 \%$ V & $1.19(0.12)$ & $0.16(0.05)^{\#}$ \\
$50 \%$ V & $0.88(0.04)$ & $0.12(0.04)^{\#}$ \\
$25 \%$ TDF $+10 \%$ BTMSE & $1.24(0.05)$ & $0.27(0.05)^{\#}$ \\
\hline
\end{tabular}

*Balance of silane used in treatment was MAOP; \#values not statistically different at $95 \%$.

substitution of fluorinated silanes for 3-methacryloxypropyltrimethoxysilane (MAOP), which contains the polar oxygen atoms, appears logical. Unfortunately, fluoroalkyltrialkoxysilanes with reactive carbon double bonds to react with the monomers to form the polymer matrix are not available. However, there are several alternative choices of silanes to increase the hydrophobicity of the interfacial layer. First, hydrophobicity of the silane layer could be increased and reaction with the organic matrix maintained by silanating with mixtures of saturated fluoroalkyltrialkoxysilanes and MAOP. Second, mixtures of aminoalkyltrialkoxysilanes and MAOP could improve silanatation as shown by Chen \& Brauer (1982). Third, increasing hydrophobicity by silanating with mixtures of aromatic silanes, such as phenyltriethoxysilane, and MAOP. Fourth, increasing hydrophobicity and maintaining reaction with the matrix by using mixtures of unsaturated aliphatic silanes, such as vinyltriethoxysilane and MAOP. Fifth, increasing hydrolytic stability of the silanated layer by using mixtures of bisfunctinal alkoxy- or chloro-silanes and fluoroalkyltrialkoxysilanes with MAOP to increase crosslinking of the silane layer.

Diametral tensilestrength at $24 \mathrm{~h}$ was used to evaluate the effectiveness of the silanation, since it has been shown by Suh, Ferber \& Baez (1990) that this property was a good indicator. The tensile strength after an additional $24 \mathrm{~h}$ in $100^{\circ} \mathrm{C}$ air was to evaluate whether there was additional polymerization of the urethanedimethacrylate matrix or further condensation of the silanes. The tensile strengths after $24 \mathrm{~h}$ in $100^{\circ} \mathrm{C}$ $\mathrm{H}_{2} \mathrm{O}$ gave an indication of the hydrolytic stability, especially when compared to those samples stored in air for $24 \mathrm{~h}$ at $100^{\circ} \mathrm{C}$. Finally, the tensile strengths of samples stored for $24 \mathrm{~h}$ at RT followed by $24 \mathrm{~h}$ in $100^{\circ} \mathrm{C}$ air and then $24 \mathrm{~h}$ at $100^{\circ} \mathrm{C}$ in water, indicated the hydrolytic stability of composites that were post-cured and then subjected to strongly hydrolytic conditions. Also, storing in $100^{\circ} \mathrm{C}$ water for various times followed by mechanical testing for strength is an accepted method for evaluating the hydrolytic stability of the silane bond (Plueddemann, 1982).

Since most of the composites treated with the various silanes showed an increase in DTS after heating in air at $100^{\circ} \mathrm{C}$ compared to the control, the decreases in DTS after boiling in water at $a 100^{\circ} \mathrm{C}$ compared to the control are conservative estimates of their hydrolytic stability, since the values would be a balance between the increase in strength from the temperature effect and the decrease in strength from the hydrolytic attack. Thus, even those samples which showed no significant decrease after $24 \mathrm{~h}$ in $100^{\circ} \mathrm{C}$ water compared to the control actually suffered some hydrolytic degradation.

As a result, samples first heated to $100^{\circ} \mathrm{C}$ in air for $24 \mathrm{~h}$ followed by storing in water at $100^{\circ} \mathrm{C}$ for $24 \mathrm{~h}$ give a clearer estimate of the hydrolytic stability. Only samples silanated with $25 \% \mathrm{~V}$ and $75 \%$ MAOP showed an increase in DTS compared to the control. Furthermore, samples silanated with $25 \% \mathrm{~V}$ were the only ones that did not show a decrease in tensile strength when samples stored for $24 \mathrm{~h}$ at RT plus $24 \mathrm{~h}$ in $100^{\circ} \mathrm{C}$ air were then stored in $100^{\circ} \mathrm{C}$ water for $24 \mathrm{~h}$. The results may be the effect of using the hydrophobic vinyltriethoxysilane which also has the opportunity to react with the matrix through the carbon double bond. Samples silanated with 25\% TDF (315 MPa) and 25\% TDF plus 10\% BTMSE ( $390 \mathrm{MPa}$ ) after the above testing showed no significant change in DTS, the latter being higher but not statistically different. These data suggest that the highly hydrophobic fluorinated silane increases hydrolytic stability even though it does not contain a carbon double bond to react with the organic matrix and that used in combination with a bistrimethoxysilylethane further increases hydrolytic stability probably as a result of crosslinking the silane.

Water sorption and solubility values were less satisfactory than DTS in estimating hydrolytic stability. This result may be due to the polymer matrix being the 
same for the composites containing the same filler silanated with various silanes. Thus, the silane coupling layer had no major impact on water sorption and solubility. The low solubility of composites silanated with vinyltriethoxysilane and 3-aminopropyltrimethoxysilane, although not statistically different from the other silanated composites, lends additional support to the use of the former in improving the hydrolytic stability of composites. For whatever reason the low solubility of the aminosilane is not coupled with high DTS after storage in $100^{\circ} \mathrm{C}$ water for $24 \mathrm{~h}$.

\section{Acknowledgments}

This investigation was supported in part by USPHS Grant P50 DE09296 from the National Institute for Dental Research, Bethesda, MD 20892.

\section{References}

Chen, T.M. \& Brauer, G.M. (1982) Solvent effects on bonding organo-silane to silica surfaces. J ournal of Dental Research, 61, 1439.

Council on Dental Materials \& Devices (1975) Revised American Dental Association Specification No. 12 for denture base polymers. J ournal of the American Dental Association, 90, 451.

KURATA, S. \& YAMAZAKI, N. (1988) Effect of isocyanatosilane coupling agents on silica surface. Shika Zairyo Kikai, 7, 1729.

MOHSEN, N.M. \& CRAIG, R.G. (1995) Hydrolytic stability of silanated zirconia-silica-urethane dimethylacrylate composites. J ournal of Oral Rehabilitation, 22, 213.

Nishiyama, N., Horie, K., Teshima, H. \& Kashima, M. (1986) Effect of functional groups of silane coupling agent on adhesion. $\mathrm{N}$ ihon University J ournal of Oral Science, 12, 409.

NISHIYAMA, N., KATSUKI, H. \& HORIE, K. (1987) Adsorbed behavior of spin-labeled silane coupling agent on colloidal silica studied by electron spin resonance. J ournal of Biomedical Materials Research, 21, 1029.

Plueddemann, E.P. (1982) Performance of silane coupling agents. In: Silane Coupling A gents, p. 141. Plenum Press, New York.

Rosenstiel, S.F., DenRY, I.L., ZHU, W., GuPTA, P.K. \& VAN Der SLUYS, R.A. (1993) Fluoroalkylethyl silane coating on a moisture barrier for dental ceramics. Journal of Biomedical Materials Research, 27, 415.

Schrader, M.E., Lerner, I. \& D'OriA, F.J. (1967) Radioisotope study of coupling agents in reinforced plastics. Modern Plastics, 45, 195.

SÖDERHOLM, K.-J.M. \& SHANG, S.-W. (1993) Molecular orientation of silane at the surface of colloidal silica. Journal of Dental Research, 72, 1050.

SÖDeRholm, K.-J.M., ZIgAN, M., Ragan, M., Fischlschweiger, W. \& Bergman, M. (1984) Hydrolytic degradation of dental composites. J ournal of Dental Research, 63, 1248.

SuH, B.I., Ferber, C. \& BAEZ, R. (1990) Optimization of hybrid composite properties. J ournal of Esthetic Dentistry, 2, 44.

Umemoto, K., Kurata, S., Shimoyama, K. \& Yamanaka, A. (1990) Effect of 3-mercaptopropyltrimethoxysilane coupling agent on stainless steel and silica surface. Shika Zairyo Kikai, 9, 444.

Correspondence: Dr Robert G. Craig, School of Dentistry, The University of Michigan, 1011 N. University Avenue, Ann Arbor, MI 48109-1078, U.S.A. 